\title{
THE EXPERIENCE OF TEMS NURSES IN HANDLING TRAFFIC ACCIDENT VICTIMS IN RSUD DR. ISKAK TULUNGAGUNG
}

\author{
Maria Wisnu Kanita', Retty Ratnawati', Retno Lestari² \\ ${ }_{1,2}$ Master of Nursing Program, Faculty of Medicine, Universitas Brawijaya
}

\begin{abstract}
Emergency Medical Services (EMS) in Indonesia has not been developed comprehensively. EMS service that has been running is in RSUD dr. Iskak Tulungagung named Tulungagung Emergency Medical Services (TEMS) with the most incident call are traffic accidents. Nurses experienced some obstacles when handling the traffic accident victims which made it cannot be done optimally. This study aims to explore the experience of nurses in conducting EMS on the handling of traffic accident victims in RSUD dr. Iskak Tulungagung. The research was using qualitative method with interpretive phenomenology approach by using data analysis process based on Interpretative Phenomenological Analysis (IPA). Nine themes were obtained from 9 participants: 1) Assuming the importance of providing the best treatment, 2) Encourage team cohesiveness to facilitate handling, 3) Feel the contradictions in the self when dealing with victims, 4) Feeling the emergence of spirit in self, 5) Serving with wholeheartedly embodied with the priority of the victim, 6) Experiencing poor acceptance from the community, 7) Experiencing the limited, 8) Craving accurate service by a competent team, and 9) Feeling increasing public trust who knowing TEMS. Establishing EMS from the beginning to the current process, based on the awareness of the nurse and the relevant parties regarding the appropriate and best handling of traffic accident victims to achieve patient safety. Regular evaluation is needed from all related parties and education for community for handling of traffic accident victims in EMS service so it can be given maximally by the nurse.
\end{abstract}

Keywords: TEMS Nurse, Handling of Traffic Accident Victims

\begin{abstract}
ABSTRAK
Pelayanan Emergency Medical Services (EMS) di Indonesia belum dikembangkan secara komprehensif. Pelayanan EMS yang sudah berjalan berada di RSUD dr. Iskak Tulungagung yang dinamai dengan Tulungagung Emergency Medical Services (TEMS) dengan panggilan kejadian terbanyak adalah kecelakaan lalu lintas. Penanganan korban kecelakaan lalu lintas oleh perawat TEMS mengalami adanya hambatan sehingga penanganan belum dapat dilakukan secara maksimal. Penelitian ini bertujuan untuk mengeksplorasi pengalaman perawat dalam melakukan EMS pada penanganan korban kecelakaan lalu lintas di RSUD dr. Iskak Tulungagung. Metode penelitian yang digunakan adalah kualitatif dengan pendekatan fenomenologi interpretif dengan menggunakan proses analisa data berdasarkan Interpretative Phenomenological Analysis (IPA). Sembilan tema berhasil didapatkan dari 9 partisipan, yaitu: 1) Menganggap sangat penting memberikan penanganan yang terbaik, 2) Mengupayakan kekompakan tim untuk mempermudah penanganan, 3) Merasakan pertentangan dalam diri ketika menangani korban, 4) Merasakan munculnya semangat dalam diri, 5) Melayani dengan sepenuh hati yang diwujudkan dengan mengutamakan korban, 6) Mengalami penerimaan yang buruk dari masyarakat, 7) Mengalami adanya keterbatasan sumber daya, 8) Mendambakan pelayanan yang akurat oleh tim yang kompeten dan 9) Merasa meningkatnya kepercayaan masyarakat yang mengetahui TEMS. Membentuk EMS sejak dari awal hingga proses yang berjalan saat ini, didasarkan pada kesadaran perawat TEMS serta pihak-pihak terkait tentang adanya penanganan korban kecelakaan lalu lintas yang sesuai dan yang terbaik guna tercapainya keselamatan pasien. Diperlukan adanya evaluasi secara berkala dari seluruh pihak terkait serta edukasi kepada masyarakat luas agar penanganan korban kecelakaan lalu lintas pada layanan EMS dapat diberikan secara maksimal oleh perawat.
\end{abstract}

Kata kunci: Perawat TEMS, Penanganan Korban Kecelakaan Lalu Lintas

Jurnal Ilmu Keperawatan, Vol. 6, No.1 Mei 2018; Korespondensi : Maria Wisnu Kanita.
Universitas Brawijaya. Jalan Veteran, Ketawanggede, Lowokwaru, Ketawanggede, Kec.
Lowokwaru, Kota Malang, Jawa Timur 65145. maria_wisnu@yahoo.co.id. 089673305582.

www.jik.ub.ac.id 


\section{PENDAHULUAN}

Pelayanan EMS di Indonesia belum dikembangkan secara komprehensif (Boyle, Wallis, \& Suryanto, 2016). Selain itu kejadian cedera yang serius seperti akibat kecelakaan lalu lintas hanya sedikit yang menggunakan ambulans untuk transportasi ke layanan kesehatan terdekat (WHO, 2015).

Sistem layanan EMS dikembangkan sesuai dengan keadaan serta kebutuhan dari masing-masing negara. Di Indonesia perawat ikut dilibatkan dalam layanan pra rumah sakit karena tidak adanya pendidikan pra rumah sakit bagi perawat (Boyle, Wallis, \& Suryanto, 2016). Pelayanan EMS yang sudah berjalan di Indonesia berada di RSUD dr. Iskak Tulungagung yang dinamai dengan Tulungagung Emergency Medical Services (TEMS). TEMS menerima panggilan kejadian terbanyak adalah kecelakaan lalu lintas.

Korban kecelakaan lalu lintas di negara berkembang rata-rata masih belum merasakan adanya layanan EMS karena belum memiliki adanya sistem transportasi dari tempat kejadian hingga ke layanan kesehatan terdekat yang didukung dengan adanya tenaga yang terlatih, ambulans dan peralatan yang lengkap didalamnya (Nielsen et al., 2012; WHO, 2015). Keterbatasan dalam layanan EMS akan menyebabkan penanganan yang kurang optimal. Tertundanya pemberian penanganan oleh EMS dapat menyebabkan cedera sekunder pada korban kecelakaan lalu lintas (Gonzales et al., 2009; Newgard et al., 2010).

Penanganan korban kecelakaan lalu lintas oleh perawat TEMS memiliki beberapa hambatan. Adanya keterbatasan sumber daya manusia, adanya batasan kewenangan serta pengambilan keputusan yang berbeda serta adanya hambatan di tempat kejadian kecelakaan saat memberikan penanganan pada korban kecelakaan lalu lintas.

Tim EMS yang terdiri dari multidisipliner akan memiliki tanggungjawab serta persepsi yang berbeda sehingga dapat menyebabkan hambatan dalam komunikasi (Berben et al., 2012). Berdasarkan Aminizadeh (2014) perawat juga akan merasakan adanya tekanan akibat adanya permasalah kultural yang ada di masyarakat. Beberapa tenaga kesehatan yang bertugas di EMS juga menyatakan memiliki pengalaman menerima adanya gangguan berupa verbal di tempat kejadian sehingga mempengaruhi penanganan (Bigham, 2014).

Penelitian mengenai "Pengalaman Perawat dalam Melakukan EMS pada Penanganan Korban Kecelakaan Lalu Lintas di RSUD Dr. Iskak Tulungagung" diharapkan dapat menunjang pengembangan penanganan korban kecelakaan lalu lintas di pelayanan TEMS khususnya oleh perawat di Indonesia.

\section{METODE}

Penelitian ini menggunakan desain penelitian kualitatif dengan pendekatan fenomenologi interpretif. Partisipan yang terlibat dalam penelitian ini berjumlah 9 orang yang ditentukan melalui purposive sampling yang sesuai dengan kriteria inklusi yaitu: 1) Memiliki pengalaman dalam melakukan penanganan korban kecelakaan, 2) Sehat jasmani dan rohani, 3) Mampu menceritakan pengalamannya secara lisan dengan baik, 4) Bersedia menjadi partisipan. 
Keseluruhan partisipan merupakan perawat laki-laki dengan kisaran umur antara 25 33 tahun dan telah melakukan pelatihan Ambulance Protocol. Pengumpulan data dilakukan dengan indepth interview dan field note. Wawancara dilakukan dengan kisaran waktu 30 - 60 menit yang direkam dengan alat perekam. Setelah data tersaturasi, data dianalisis menggunakan proses analisa data berdasarkan Interpretative Phenomenological Analysis (IPA), yaitu: Reading and Re-reading, Initial Noting, Developing Emergent Themes, Searching for connection a cross emergent themes, Moving the next cases, dan Looking for patterns across cases.

\section{HASIL PENELITIAN}

Hasil penelitian yang didapatkan berdasarkan tujuan penelitian diperoleh sembilan tema, yaitu: 1) Termotivasi untuk memberikan penanganan yang terbaik, 2) Mengupayakan kekompakan tim untuk mempermudah penanganan, 3) Merasakan pertentangan dalam diri ketika menangani korban, 4) Merasakan munculnya semangat positif dalam diri, 5) Melayani dengan sepenuh hati yang diwujudkan dengan mengutamakan korban, 6) Mengalami penerimaan yang buruk dari masyarakat, 7) Mengalami adanya keterbatasan sumber daya yang membuat penanganan menjadi lebih sulit, 8) Mendambakan pelayanan yang akurat oleh tim yang kompeten, dan 9) Merasa meningkatnya kepercayaan masyarakat yang mengetahui TEMS

Tema-tema tersebut dijelaskan sebagai berikut:

\section{Menganggap sangat penting memberikan penanganan yang terbaik}

Tema ini terdiri dari dua sub tema. Sub tema pertama adalah berpikir penanganan yang sesuai kepada korban adalah hal yang utama, dengan pernyataan partisipan sebagai berikut:

“... tapi dari sisi pokoknya orang itu tertolong dulu dan selamat sampai IGD sambil kita melakukan penanganan di dalam ambulan. ... Ya pokoknya keselamatan nyawa si korban itu yang kita utamakan terlebih dahulu selain semua. Pokoknya selamat, ... " (P1)

Pernyataan di atas menunjukkan bahwa partisipan menganggap bahwa penanganan pasien itu harus diutamakan supaya korban dapat melewati masa gawat dan dapat tertolong.

Sub tema kedua adalah memahami untuk menolong dengan segala kemampuan yang dimiliki, dengan pernyataan partisipan sebagai berikut:

"Kan sudah ada di RS, walaupun bukan RS semestinya, tapi ini kan RS berjalan." (P1)

"Jadi sangat membantu sekali bagi pasien yang sangat perlu penanganan medis." (P7)

Pernyataan diatas menunjukkan bahwa partisipan menganggap bahwa kehadiran partisipan dapat membantu bagi pasien kecelakaan lalu lintas di lokasi kejadian yang membutuhkan penanganan dari layanan kesehatan seperti di RS. 


\section{Mengupayakan kekompakan tim untuk mempermudah penanganan}

Tema ini terdiri dari sub tema meyakini kesepahaman itu penting, dengan pernyataan partisipan sebagai berikut:

"Yang penting koordinasi antar kru, sudah saling memahami..." (P3)

"Ketika saya sudah memasang ini, inisiatif dari temen itu pegang yang lainnya. Dengan saling melengkapi seperti itu pasien cepet tertangani, kemudian pasien sampai di RS itu tindakan sudah selesai." (P2)

Pernyataan diatas menunjukkan bahwa partisipan menganggap bahwa perawat TEMS yang saling memahami dan berkoordinasi akan mampu menangani korban dengan cepat.

\section{Merasakan pertentangan dalam diri ketika menangani korban}

Tema ini terdiri dari dua sub tema. Sub tema pertama adalah merasa menyalahkan diri sendiri karena kematian korban, dengan pernyataan partisipan sebagai berikut:

"...Kita menyayangkan sekali kalau

korban tidak dapat selamat.." (P4)

Pernyataan diatas menunjukkan bahwa partisipan sangat menyayangkan ia tidak dapat menyelamatkan korban.

Sub tema kedua adalah merasakan gangguan akibat masyarakat dan polisi yang tidak mendukung, dengan pernyataan partisipan sebagai berikut:

"Kita menangani ... ada tekanan dari masyarakat.." (P6)

"Ya mangkel sih mbak, Iha piye maneh kene wis tergesa-gesa kok dingonokke uwong-uwong (ya jengkel sih mbak, Iha gimana lagi sini sudah tergesa-gesa masih digitukan juga sama warga).." (P5)

Pernyataan di atas menunjukkan bahwa partisipan merasa kesal dengan warga yang kurang paham sehingga memberikan tekanan kepada partisipan dalam berusaha menangani korban kecelakaan lalu lintas.

\section{Merasakan munculnya semangat dalam diri}

Tema ini terdiri dari dua sub tema. Sub tema pertama adalah tulus dalam melakukan penanganan, dengan pernyataan partisipan sebagai berikut:

"Gak usah golek jeneng neng kono, gak usah pamer(tidak usah cari nama disana, tidak usah pamer)..."(P1)

Pernyataan di atas menunjukkan bahwa partisipan tulus dalam melakukan tindakan.

Sub tema kedua adalah berpuas diri atas penanganan yang dilakukan, dengan pernyataan partisipan sebagai berikut:

"...ketika sudah menyampaikan

Beliaunya sampai di IGD dengan keadaan selamat... Itu sudah puas." (P1)

"Perasaan seneng itu ya ada bisa menyampaikan pasien dengan selamat ke IGD..." (P4)

Pernyataan diatas menunjukkan bahwa partisipan merasa puas dan senang dapat menolong dan menyelamatkan korban.

5. Melayani dengan sepenuh hati yang diwujudkan dengan mengutamakan korban

Tema ini terdiri dari tiga sub tema. Sub tema pertama adalah berusaha fokus pada 
penanganan pasien, dengan pernyataan partisipan sebagai berikut:

“...penanganannya yang pertama kita lakukan primary survey ... kemudian kita bawa ke ambulan, load and go ... dalam perjalanan kita lakukan secondary survey ... kita berpatokan pada response time itu" (P1)

"Untuk yang lainnya saya sampingkan dulu, yang penting keselamatan pasien itu sendiri sampai tiba di RS bagaimana untuk mendapatkan perawatan lanjutan..." (P1)

Pernyataan di atas menunjukkan bahwa partisipan melakukan tindakan kepada korban sesuai dengan prosedur yang harus dilakukan dan berfokus kepada penanganan agar keselamatan pasien dapat teraih.

Sub tema kedua adalah menyesuaikan peran dalam penanganan, dengan pernyataan partisipan sebagai berikut:

$$
\begin{aligned}
& \text { "...Kita disitu tetap sebagai } \\
& \text { leader..." (P1) }
\end{aligned}
$$

Pernyataan diatas menunjukkan bahwa partisipan di lokasi kejadian tetap menjalankan perannya saat menangani korban kecelakaan lalu lintas, yaitu sebagai leader.

Sub tema ketiga adalah melakukan koordinasi selama penanganan, dengan pernyataan partisipan sebagai berikut:

"...Kita berkoordinasi dengan polisi di tempat kejadian" (P7)

"Menginformasikan gimana keadaan pasien sekarang, terjadi apa, kepada call center..."(P1)

Pernyataan di atas menunjukkan bahwa partisipan melakukan koordinasi dengan polisi di lokasi kejadian serta perawat di call center atas keadaan pasien.

\section{Mengalami penerimaan yang buruk dari masyarakat}

Tema ini terdiri dari dua sub tema. Sub tema pertama adalah mengalami gangguan akibat masyarakat tidak mengerti, dengan pernyataan partisipan sebagai berikut:

"Kalau pendidikan masyarakat semakin rendah mungkin dengan dijelaskan kondisinya seperti ini, yang gawat yang ini, yang enggak yang ini, yang ditangani yang ini dulu, kan masih kurang paham.." (P2)

Pernyataan di atas menunjukkan bahwa partisipan menjelaskan ke masyarakat tentang penanganan yang tepat tetapi masyarakat tidak paham.

Sub tema kedua adalah merasa tidak dipercaya oleh masyarakat untuk menangani korban, dengan pernyataan partisipan sebagai berikut:

“...Pernah datang ke lokasi kejadian, sampai sana pasien sudah dibawa warga" (P3)

"... mereka cenderung meremehkan,

"kon iku sopo?" (Anda itu siapa?).

Masio (walaupun) daerah sepi kalau ada kecelakaan..." (P1)

Pernyataan diatas menunjukkan bahwa mendapati adanya masyarakat yang tidak mempercayai TEMS sehingga korban dibawa sendiri oleh masyarakat ke RS dan adanya warga yang meremehkan di lokasi kejadian.

\section{Mengalami adanya keterbatasan sumber daya}

Tema ini terdiri dari tiga sub tema. Sub tema pertama adalah menemukan adanya 
kekurangan dari dalam tim, dengan pernyataan partisipan sebagai berikut:

"...Ya mungkin sebagai manusia kekurangan dari kami kurang update." (P1)

"Ya mungkin dari tenaganya yang terbatas, "(P1)

Pernyataan diatas menunjukkan bahwa partisipan merasa tidak memiliki ilmu yang terbarukan dan merasakan adanya keterbatasan tenaga.

Sub tema kedua adalah menemukan kesulitan akibat keterbatasan lahan, dengan pernyataan partisipan sebagai berikut:

"...tindakan infus yang menjadi kendala itu. Waktu ambulan berjalan itu waktu kita nginfus itu, ya walau sudah distiweng (di torniket) dengan teman-teman ... namanya ambulan berjalan goyang kan ya itu kesulitan kita disitu." (P1)

"Kalau di jalan raya itu tidak ada masalah ya mbak ya, kalau di jalan yang kayak jalan kelinci yang njepitnjepit, jalanan kecil gitu. Ketika ada kecelakaan, masuk got, masuk sungai, nah itu hambatan kita...." (P7)

Pernyataan diatas menunjukkan bahwa partisipan kesulitan melakukan penanganan di ambulan yang sempit dan lokasi kejadian yang tidak terlalu luas.

Sub tema ketiga adalah mengalami adanya batasan kewenangan tindakan dengan pernyataan partisipan sebagai berikut:

"...Walaupun enggak menutup kemungkinan dari perawatnya itu sendiri sudah sanggup untuk ETT, tapi kalau enggak ada dokternya kan kita enggak...ya berani sih berani, tapi untuk yang bertanggungjawab itu yang menjadi kendala....."(P1)

Pernyataan diatas menunjukkan bahwa partisipan tidak dapat bertanggungjawab untuk tindakan yang bukan menjadi kewenangan perawat walaupun korban sebenarnya membutuhkan penanganan tersebut.

\section{Mendambakan pelayanan yang akurat oleh tim yang kompeten}

Tema ini terdiri dari empat sub tema. Sub tema pertama adalah menginginkan terciptanya layanan yang meningkat bagi masyarakat, dengan pernyataan partisipan sebagai berikut:

"...Nanti kalau sudah berjalan sebagai mana mestinya karena ini program baru, kalau sudah berjalan, kita bisa tingkatkan ke arah itu." (P1)

"Pengennya semua pasien kecelakaan khususnya di daerah Tulungagung dapat ditangani oleh orang-orang yang kompeten dibidangnya..." (P3)

Pernyataan di atas menunjukkan bahwa partisipan menginginkan adanya peningkatan pelayanan yang dilakukan dalam TEMS serta seluruh korban kecelakaan lalu lintas dapat ditangani oleh TEMS secara keseluruhan.

Sub tema kedua adalah berharap adanya peningkatan kompetensi tim, dengan pernyataan partisipan sebagai berikut:

"...Jadi harapanya enggak hanya ambulan protokol, jadi secara 
kontinyu kita bisa melakukan pelatihan bersama. Jadi, lebih mematangkan atau lebih memantapkan pengananan di lokasi..." (P2)

Pernyataan di atas menunjukkan bahwa partisipan menginginkan adanya pelatihan yang dilakukan secara bersama mengenani penanganan korban kecelakaan lalu lintas di lokasi kejadian.

Sub tema ketiga adalah berharap baik korban maupun penolong dapat selamat, dengan pernyataan partisipan sebagai berikut:

"...Yang penting kita harapannya pasien itu selamat dan penolong. ... supaya korban kita itu, teman kita itu selamat sampai IGD. Tidak ada yang lain." (P1)

Pernyataan di atas menunjukkan bahwa partisipan berharap pasien dan perawat dapat selamat sampai di IGD.

Sub tema keempat adalah enginginkan adanya perubahan persepsi masyarakat tentang TEMS, dengan pernyataan partisipan sebagai berikut:

"... jadi dilihat masyarakat, "oh ternyata ini kita memang safety, dari ambulan datang, ditangani seperti itu, wah ternyata aman daripada kita angkut" kan seperti itu. Harapannya konsep warga atau masyarakat kan seperti itu." (P6)

"Harapannya kedepannya masyarakat enggak mindah pasien, tapi langsung nelfon kita." (P9)

Pernyataan di atas menunjukkan bahwa partisipan berharap masyarakat tidak memindah korban dan menunggu perawat TEMS datang untuk melakukan penanganan.

\section{Merasa meningkatnya kepercayaan masyarakat yang mengetahui TEMS}

Tema ini terdiri dari dua sub tema. Sub tema pertama adalah mendapati adanya peningkatan penggunaan layanan TEMS, dengan pernyataan partisipan sebagai berikut:

"...Dan saat ini pun sudah sampai 80 sampai 100 pun ada panggilan setiap bulannya." (P2)

"Sekarang ini sudah banyak korban yang dibawa oleh TEMS ke RS daripada masyarakat awam..." (P8)

Pernyataan di atas menunjukkan bahwa partisipan mendapati adanya peningkatan telepon masyarakat dan peningkatan korban kecelakaan lalu lintas yang dibawa oleh perawat TEMS.

Sub tema kedua adalah merasa dipercaya oleh masyarakat, dengan pernyataan partisipan sebagai berikut:

“...banyak juga Iho Mbak yang kalau daerah sini itu sampai bilang ke kita, waktu itu bilang "Koyo nang Amerika Amerika yo..." ("Seperti di Amerika Amerika ya...").." (P1)

"Kalau ngerti ya tetep nunggu kita. ... Dilihat dari waktu kita ke TKP itu masyarakat "Awas, awas, awas.." ya maksudnya itu biar cepat ditangani..." (P1)

Pernyataan di atas menunjukkan bahwa partisipan merasa dianggap mampu oleh masyarakat dan memberikan kesempatan kepadanya untuk menangani korban kecelakaan lalu lintas.

Sub tema ketiga adalah usaha peningkatan penanganan korban, dengan pernyataan partisipan sebagai berikut: 
"sudah koordinasi dengan manajemen," (P1)

Pernyataan di atas menunjukkan bahwa partisipan sudah melakukan adanya usaha untuk melakukan peningkatan dalam penanganan korban dengan dilakukannya koordinasi dengan pihak manajemen.

Sub tema keempat adalah masyarakat memberikan tanggapan positif, dengan pernyataan partisipan sebagai berikut:

"banyak juga Iho Mbak yang kalau daerah sini itu sampai bilang ke kita, waktu itu bilang "Koyo nang Amerika Amerika yo..." ("Seperti di Amerika Amerika ya...") (P1)

Pernyataan di atas menunjukkan bahwa masyarakat mempercayai dan beranggapan bahwa layanan EMS yang dilakukan partisipan seperti layanan EMS yang ada di Amerika.

\section{Interaksi Antar Tema}

Perawat TEMS memahami untuk dapat memberikan penanganan yang terbaik bagi korban kecelakaan lalu lintas. Disamping itu perawat TEMS juga selalu mengutamakan kekompakan tim untuk mempermudah penanganan. Hal itu dilandasi karena perawat TEMS menyadari bahwa ia bekerja didalam tim dan dituntut untuk mampu memberikan penanganan yang cepat dan tepat agar keselamatan korban dapat dicapai. Mengutamakan keadaan korban juga selalu dipegang teguh oleh perawat TEMS dalam memberikan pelayanan sepenuh hati. Perawat TEMS juga merasakan adanya beberapa kendala dalam penanganan. Mendapatkan penerimaan yang buruk dari masyarakat yang belum mengetahui TEMS serta adanya keterbatasan sumber daya membuat penanganan menjadi lebih sulit. Hal tersebut mengakitbatkan adanya pertentangan dalam diri ketika menangani korban. Masyarakat yang mengerti bahwa pelayanan yang tulus diberikan oleh perawat TEMS kemudian berimbas pada meningkatnya kepercayaan yang mengerti bagaimana perawat TEMS menangani korban kecelakaan lalu lintas. Hal tersebut memunculkan adanya semangat positif dalam diri sehingga perawat TEMS mendambakan adanya pelayanan yang akurat oleh tim yang kompeten. Hal tersebut kemudian kembali lagi kepada motivasi perawat TEMS untuk dapat memberikan penanganan yang terbaik bagi masyarakat terutama korban kecelakaan lalu lintas.

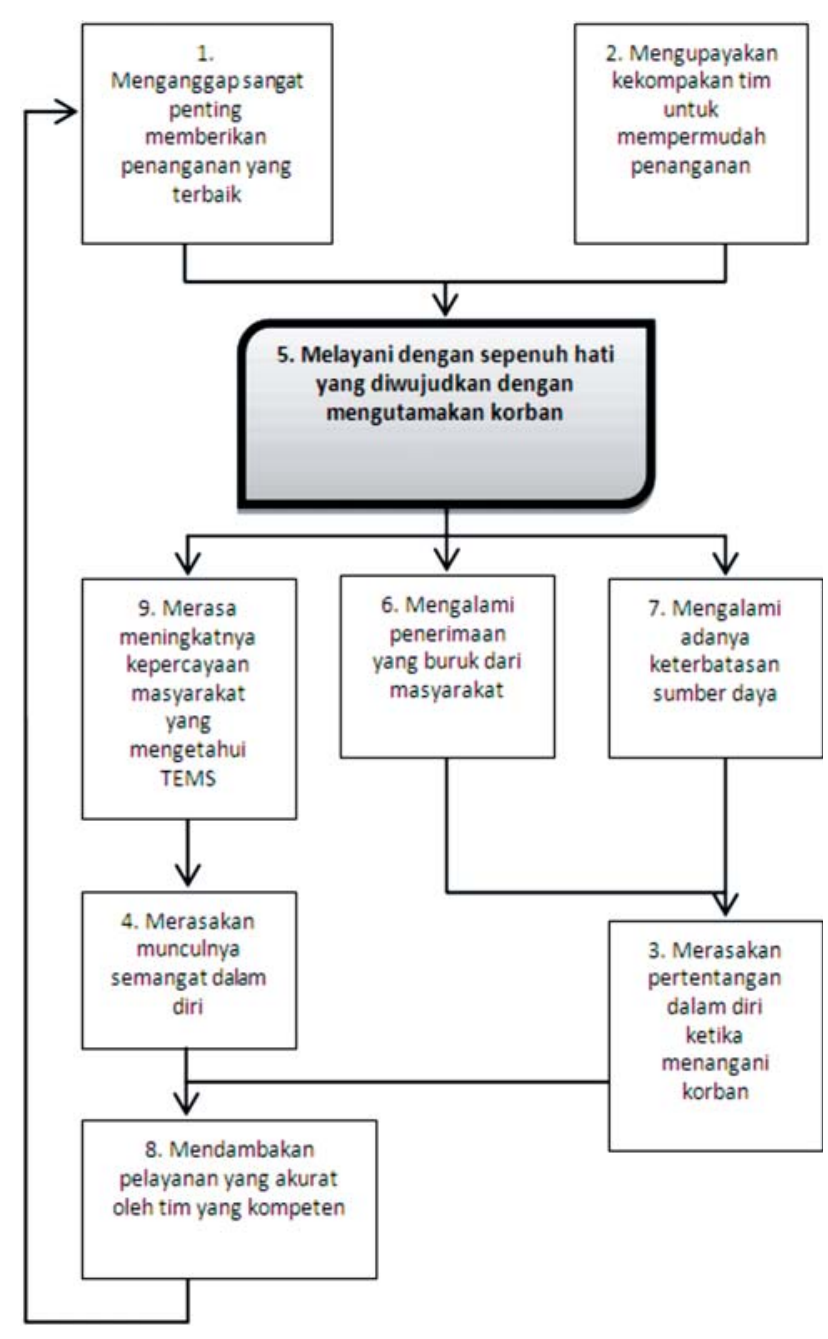

Skema 1. Interaksi Antar Tema Jurnal Ilmu Keperawatan - Volume 6, No. 1 Mei 2018 


\section{PEMBAHASAN}

Penanganan korban kecelakaan lalu lintas memerlukan suatu mekanisme yang terintegrasi dari tempat kejadian hingga ke layanan kesehatan seperti bentuk pelayanan EMS (Djaja et al., 2016). Perawat yang tergabung pada layanan EMS sepenuhnya sadar jika tindakan yang dilakukan di EMS merupakan tindakan penanganan kepada korban kecelakaan lalu lintas yang harus dilakukan secara fokus pada penanganan bagi pasien dan memberikan penanganan yang terbaik pula.

Penelitian lain menyatakan bahwa perawat yang tergabung dalam layanan EMS merasa harus mempersiapkan diri dan menciptakan kondisi untuk perawatan yan baik. Selain itu perawat merasa harus mencapai perawatan yang terbaik yang dekat dengan pasien yang membutuhkan penanganan gawat darurat di luar rumah sakit (Holmberg \& Fagerberg, 2010).

Perawat yang tergabung dalam layanan EMS akan memerlukan adanya koordinasi dan kerjasama dengan berbagai pihak dalam melakukan penanganan korban kecelakaan lalu lintas. Penelitian menyatakan bahwa partisipan merasa memerlukan adanya kerjasama tim yang terwujud dengan adanya kerjasama dengan tim.

Penelitian yang dilakukan oleh Bigham et al. (2010) menyatakan bahwa personel yang melakukan layanan EMS yang mengaplikasikan sebuah urutan prosedur akan merasakan adanya hambatan terkait dengan pengambilan keputusan karena bekerja sama dengan banyak pihak terkait.

Latar belakang pendidikan personel juga menjadi hal yang dapat mempengaruhi dalam capaian utama layanan, sehingga hal tersebut harus dipertimbangkan dalam pengembangan layanan EMS (Gondocs et al., 2009).

Perawat yang tergabung dalam layanan EMS akan menjumpai berbagai macam hal di lokasi kejadian yang terkadang tidak ditemukan pada layanan intra RS. Perawat merasakan kecewa terhadap diri sendiri karena tidak mampu menolong korban, kasihan ketika mendapati korban kecelakaan sudah tidak bernyawa dan merasa kasihan saat menemukan rekan sejawat menjadi korban kecelakaan itu sendiri. Selain itu perawat merasakan adanya kepanikan, merasa mendapat tekanan, dan merasa terganggu karena masyarakat yang tidak paham.

Aminizadeh (2014) menyatakan ketika melakukan penanganan kepada pasien akan merasakan adanya tekanan akibat adanya permasalah kultural yang ada di masyarakat. Beberapa tenaga kesehatan yang bertugas di EMS juga menyatakan memiliki pengalaman menerima adanya gangguan berupa verbal maupun intimidasi ketika sedang melakukan penanganan di tempat kejadian sehingga mempengaruhi penanganan (Bigham, 2014).

Adanya koordinasi yang baik dengan pihak lain seperti polisi saat melakukan penanganan di tempat kejadian akan membuat perawat merasa nyaman melakukan tindakan seperti di RS. Perawat juga merasa senang melakukan tindakan di EMS karena dapat menemui berbagai macam kasus yang ada dan merasa bersyukur dapat dipercaya oleh masyarakat untuk dapat membantu orang lain, khususnya korban kecelakaan lalu lintas. 
Romanzini dan Bock (2010) menyatakan bahwa perawat yang bekerja di EMS merasa aman, siap dan termotivasi untuk bekerja dan mereka juga mengalami perasaan yang beragam seperti kasih sayang, rasa syukur, marah, kasihan, kesedihan dan kecemasan. Aminizadeh (2014) menyatakan ketika melakukan penanganan kepada pasien akan merasakan adanya tekanan akibat adanya permasalah kultural yang ada di masyarakat.

Perawat TEMS berusaha melakukan tindakan kepada korban kecelakaan lalu lintas dengan selalu memperhatikan keselamatan korban. Tujuan utama EMS adalah memberikan perawatan darurat kepada pasien yang membutuhkan penanganan dengan segera dan memindahkan mereka ke layanan kesehatan yang tepat yang dibutuhkan (Al-Shaqsi, 2010).

EMS harus mampu memberikan penanganan yang sesuai dengan keadaan korban. Tetapi peningkatan waktu tanggap dari EMS, peningkatan penanganan di tempat kejadian, serta semakin jauhnya tempat kejadian, dapat berkontribusi pada kematian korban kecelakaan lalu lintas (Gonzalez, et al., 2009). Perawat merasa bahwa penanganan yang cepat dan sesuai harus diberikan dengan segera kepada korban kecelakaan lalu lintas.

Kendala-kendala juga dirasakan oleh perawat dalam melakukan tindakan. Adanya kendala karena kebiasaan masyarakat ketika terdapat kejadian kecelakaan lalu lintas dengan mengerumuni korban dan ketidakmampuan masyarakat menerima penjelasan dari perawat untuk menangani korban yang lebih gawat. Selain itu adanya masyarakat yang meremehkan perawat TEMS.

Aminizadeh (2014) menyatakan ketika melakukan penanganan kepada pasien akan merasakan adanya tekanan akibat adanya permasalah kultural yang ada di masyarakat. Beberapa tenaga kesehatan yang bertugas di EMS juga menyatakan memiliki pengalaman menerima adanya gangguan berupa verbal maupun intimidasi ketika sedang melakukan penanganan di tempat kejadian sehingga mempengaruhi penanganan (Bigham, 2014).

Kementerian Kesehatan Republik Indonesia sedang mengembangkan layanan pra rumah sakit untuk keadaan gawat darurat maupun trauma. Tetapi tidak ada jaminan yang pasti bahwa layanan pra rumah sakit tersebut dapat diaplikasikan dengan baik karena adanya kekurangan di infrastuktur maupun sumber daya yang mampu mengelola keadaan gawat darurat (Boyle, Wallis, \& Suryanto, 2016).

Adanya kesulitan dalam melakukan koordinasi dengan tim maupun diluar tim. Merasakan adanya kesulitan dalam melakukan tindakan selama di dalam perjalanan karena. Selain itu juga terdapat dilema etik dalam melakukan penanganan pada korban, yaitu disaat korban membutuhkan penanganan yang bukan kewenangan perawat sebagai perawat.

Tim EMS memiliki banyak tuntutan dan tantangan. Maragh-Bass, Fields, McWilliams, Knowlton (2017) menyatakan bahwa personel EMS mengakui adanya keterbatasan waktu serta sumber daya yang membuat penanganan EMS menjadi lebih sulit. Selain itu personel EMS juga 
menyatakan bahwa prosedur praktik klinik terkadang sulit untuk diterapkan di setting EMS yang kejadiannya tidak dapat diduga (Bigham et al., 2010).

Harapan-harapan atas pelayanan EMS yang diberikan perawat kepada korban kecelakaan lalu lintas muncul dalam hasil penelitian. Hal tersebut berupa adanya keinginan untuk meningkatkan pelayanan yang diberikan kepada masyarakat, keinginan untuk lebih meningkatkan kompetensi diri dengan adanya pelatihan yang dilakukan secara berkala.

Personel yang terlatih yang melakukan layanan EMS merupakan hal yang wajib dilakukan. Hal tersebut dikarenakan pasien yang dihadapi adalah pasien dengan keadaan yang mungkin mengancam nyawa. Mengingat hal tersebut maka personel EMS yang terlatih merupakan hal yang selalu dijumpai sejak dari awal perkembangan EMS (Al-Shaqsi, 2010).

Keinginan yang muncul dari perawat tersebut merupakan perwujudan dari rasa tanggung jawab perawat dalam bertugas. Dimana hal tersebut merupakan sebuah fenomena yang kompleks, dengan perspektif caring, yang muncul dari pertemuan dengan keadaan manusia yang unik (Holmberg \& Fagerberg, 2010).

Beberapa tahun lalu, EMS adalah istilah yang lebih digunakan untuk pengawasan dan transportasi pasien ke layanan kesehatan yang tepat. Saat ini EMS mengacu pada penanganan pra-rumah sakit yang diberikan kepada pasien darurat dan dilakukan transportasi ke fasilitas kesehatan yang sesuai dengan keadaan pasien (Sánchez-Mangas et al., 2010).
Dengan adanya penanganan korban kecelakaan oleh tim EMS yang mulai berjalan, masyarakat dapat melihat adanya usaha dari tim kesehatan untuk dapat melakukan penanganan korban kecelakaan lalu lintas secara tepat dan cepat. Hal tersebut menimbulkan masyarakat memberikan tanggapan positif berupa merasa tenang dan mempercayai penanganan yang diberikan oleh tim EMS.

\section{SIMPULAN}

Berdasarkan hasil penelitian dapat disimpulkan bahwa perawat TEMS termotivasi untuk memberikan penanganan yang terbaik bagi korban kecelakaan lalu lintas. Keinginan untuk memberikan pelayanan pra rumah sakit oleh perawat TEMS menimbulkan adanya usaha untuk dengan kesungguhan hati agar korban dapat selamat. Perawat EMS menginginkan adanya peningkatan-peningkatan yang diberikan dalam layanan EMS. Hal tersebut didasari pada keinginan kuat untuk dapat memberikan penanganan yang maksimal agar dapat menyelamatkan nyawa korban kecelakaan lalu lintas.

Perlu dilakukan evaluasi secara berkala dari seluruh pihak terkait agar dapat menangani kendala yang dirasakan oleh perawat. Diperlukan pula sosialisasi kepada masyarakat secara menyeluruh dan berkala agar permasalahan terkait kebiasaan masyarakat, pendidikan dan kesadara masyarakat yang masih beragam dapat tertangani sehingga layanan EMS yang diberikan oleh perawat kepada korban kecelakaan lalu lintas dapat diberikan secara maksimal. 


\section{DAFTAR PUSTAKA}

Al-Shaqsi, S. (2010). Models of International Emergency Medical Service (EMS) Systems, Oman Medical Journal. 25 (4): 320-323.

Aminizadeh, M., et al. (2014). Experiences of emergency medical service personnel: (A qualitative study), J Nov. App/ Sci. 3 (9): 967-970.

Berben, S.A.A., et al. (2012). Facilitators and barriers in pain management for trauma patients in the chain of emergency care, Injury, Int. J. Care Injured. 43: 1397-1402.

Bigham, B.L., et al. (2010). Knowledge translation in emergency medical services: A qualitative survey of barriers to guideline implementation, $J$. Resuscitation. 81: 836-840.

Bigham, B.L., et al. (2014). Paramedic Self-reported Exposure to Violence in the Emergency Medical Services (EMS) Workplace: A Mixed-methods Crosssectional Survey, Journal Prehospital Emergency Care. 18 (4) : 489-494.

Boyle, M., Wallis, J., \& Suryanto. (2016). Pre-hospital care in developing countries, Australasian Journal of Paramedicine. 13 (3) : 1-2.

Djaja, S., et al. (2016). Gambaran Kecelakaan Lalu Lintas Di Indonesia Tahun 20102014, Jurnal Ekologi Kesehatan. 15 (1): $30-42$.

Gondocs, Z., et al. (2010). Prehospital Emergency Care in Hungary: What can we learn from the past?,The Journal of Emergency Medicine. 39 (4): 512-518.

Gonzalez, R.P., et al. (2009). Does increased emergency medical services prehospital time affect patient mortality in rural motor vehicle crashes? A statewide analysis, The American journal of surgery. 197 (1): 30-34.

Holmberg, M., \& Fagerberg, I. (2010). The encounter with the unknown: Nurses lived experiences of their responsibility for the care of the patient in the Swedish ambulance service, Int J Qual Stud Health Well-being. 5 (2) : 1-9.

Maragh-Bass, A.C., Fields, J.C., McWilliams, J., dan Knowlton, A.R. (2017). Challenges and Opportunities to Engaging Emergency Medical Service Providers in Substance Use Research: A Qualitative Study, Prehosp Disaster Med. 26:1-8.

Newgard, C. D., et al. (2010). Emergency medical services intervals and survival in trauma: assessment of the "Golden Hour" in a North American Prospective Cohort, Annals of Emergency Medicine. 55 (3): 235-240.

Nielsen, K., et al. (2012). Assessment of the Status of Prehospital Care in 13 Low and Middle-Income Countries, Journal Prehospital Emergency Care. 16 (3):

Romanzini, E. M., \& Bock, L. F. (2010). Conceptions and feelings of nurses working in emergency medical services about their professional practice and training, Rev Lat Am Enfermagem. 18 (2) : 240-246.

Sánchez-Mangas, R., et al. (2010). The probability of death in road traffic accidents. How important is a quick medical response?,Accident Analysis and Prevention. 42 (2010): 1048-1056.

WHO. (2015). Global status report on road safety 2015. WHO: Switzerland. 